\title{
El Catálogo General del Patrimonio Histórico Andaluz en el valle del Almanzora
}

El valle del Almanzora lo conforman 41 municipios (seis afectados parcialmente), de los cuales en 31 tenemos repartidos 107 bienes que están incluidos en el Catálogo General del Patrimonio Histórico, además de dos que son zona de servidumbre arqueológica (figura que no se anota en el Catálogo al tratarse de una protección cautelar de restos supuestos, si bien sin una evidencia arqueológica constatada).

Si los clasificamos por la figura legal y por la tipología jurídica que les da protección, obtenemos:

\begin{tabular}{lr}
\hline BIENES DE INTERÉS CULTURAL & \\
\hline Monumento & 61 \\
Zona arqueológica & 13 \\
\hline BIENES DE CATALOGACIÓN GENERAL & \\
\hline Ermitas & 5 \\
Patrimonio minero & 24 \\
Otros & 4 \\
\hline
\end{tabular}

ZONA DE SERVIDUMBRE ARQUEOLÓGICA

\begin{tabular}{lr}
\hline ZSA & 2 \\
\hline TOTAL DE BIENES & 109
\end{tabular}

La comarca del Almanzora a lo largo de su historia ha dejado un gran legado tanto arqueológico como arquitectónico. De la etapa prehistórica tenemos los primeros vestigios patrimoniales representados por cinco cuevas con pinturas rupestres, pero sobre todo habria que destacar los yacimientos que se remontan al II milenio a. de C. de la cultura del Argar, una de las culturas más importantes de la Edad del Bronce en Europa. Su definición y sistematización se hizo a partir de las excavaciones llevadas a cabo por los hermanos Siret y donde destacan fundamentalmente los bienes de interés cultural protegidos como zonas arqueológicas de Cabezo María (21/07/1991), Lugarico Viejo (10/09/2002) y El Argar y la Gerundia (28/10/2003), todos ellos en Antas.

Otro yacimiento destacable por su amplia secuencia cronológica, con unos orígenes que se remontan a la Edad del Cobre y un hábitat que perdura hasta época altomedieval, asi como por los valores patrimoniales de sus restos, es la zona arqueológica de Villaricos, declarada bien de interés cultural el 26 de octubre de 1983, ampliándose la delimitación e inscribiéndose con carácter específico en el C.G.P.H.A. como zona arqueológica, por orden del 14 de febrero de 2005. Este yacimiento se considera clave en el estudio de la colonización fenicia en la Peninsula lbérica, identificándose con Baria, cuya fundación data del siglo VIII a. de C., centrándose en la explotación de los recursos agricolas y mineros del bajo Almanzora.

Pero fue la Edad Media la que dejó mayor patrimonio arquitectónico y cultural en la comarca. Ejemplo de ello son la multitud de construcciones y restos arqueológicos que se conservan de esta época, sobre todo en lo que se refiere a la línea de defensa del valle y a la de la costa, donde se han podido identificar un total de 47 bienes de arquitectura militar, destacando castillos y restos de fortificaciones musulmanas como las torres almenaras. Un ejemplo de relevante importancia, tanto por su amplitud espacial como significado patrimonial, es Tíjola la Vieja, medina fortificada coronada por una fortaleza y un recinto palaciego.

De edad contemporánea destaca un conjunto de elementos del patrimonio industrial minero que representa un importante testimonio de una de las épocas más fecundas de la actividad económica de la provincia, abarcando desde la primera época de la revolución industrial almeriense hasta su ocaso en la década de los sesenta del siglo pasado, constituyendo un valioso testimonio material del gran cambio experimentado en la sociedad almeriense del siglo XIX y principios del XX. Por este motivo, la Consejería de Cultura a través de la Resolución de 7 de enero de 2004, de la Dirección General de Bienes Culturales, inscribe colectivamente con carácter genérico en el Catálogo General del Patrimonio Histórico Andaluz, 44 bienes inmuebles pertenecientes al patrimonio industrial relacionados con la minería de los siglos XIX y XX en la provincia de Almería, de los cuales 24 se encuentran en la comarca del valle del Almanzora.

Por otra parte, la Ley 14/2007 de Patrimonio Histórico de Andalucía establece en la Disposición adicional sexta, punto $2^{\circ}$, que "Los bienes inmuebles del Patrimonio Histórico Andaluz (...) que se encuentren en posesión de la Administración de la Junta de Andalucia, las entidades locales y las universidades quedan inscritos en el Catálogo General del Patrimonio Histórico Andaluz como bienes de catalogación general." Éste es el caso de cinco bienes -ermitas, santuarios y calvarios rurales-, que se encuentran en cuatro municipios de la zona y que se han incluido en el Catálogo General del Patrimonio Histórico Andaluz a instancia de la Delegación Provincial de Almeria.

El Catálogo General del Patrimonio Histórico Andaluz está abierto a la consulta pública en la página web de la Consejeria de Cultura, dentro del área de Bienes Culturales: www.juntadeandalucia.es/cultura

\section{Alfonso Montejo Ráez}

Olga Viñuales Meléndez

Servicio de Protección del Patrimonio Histórico

Dirección General de Bienes Culturales

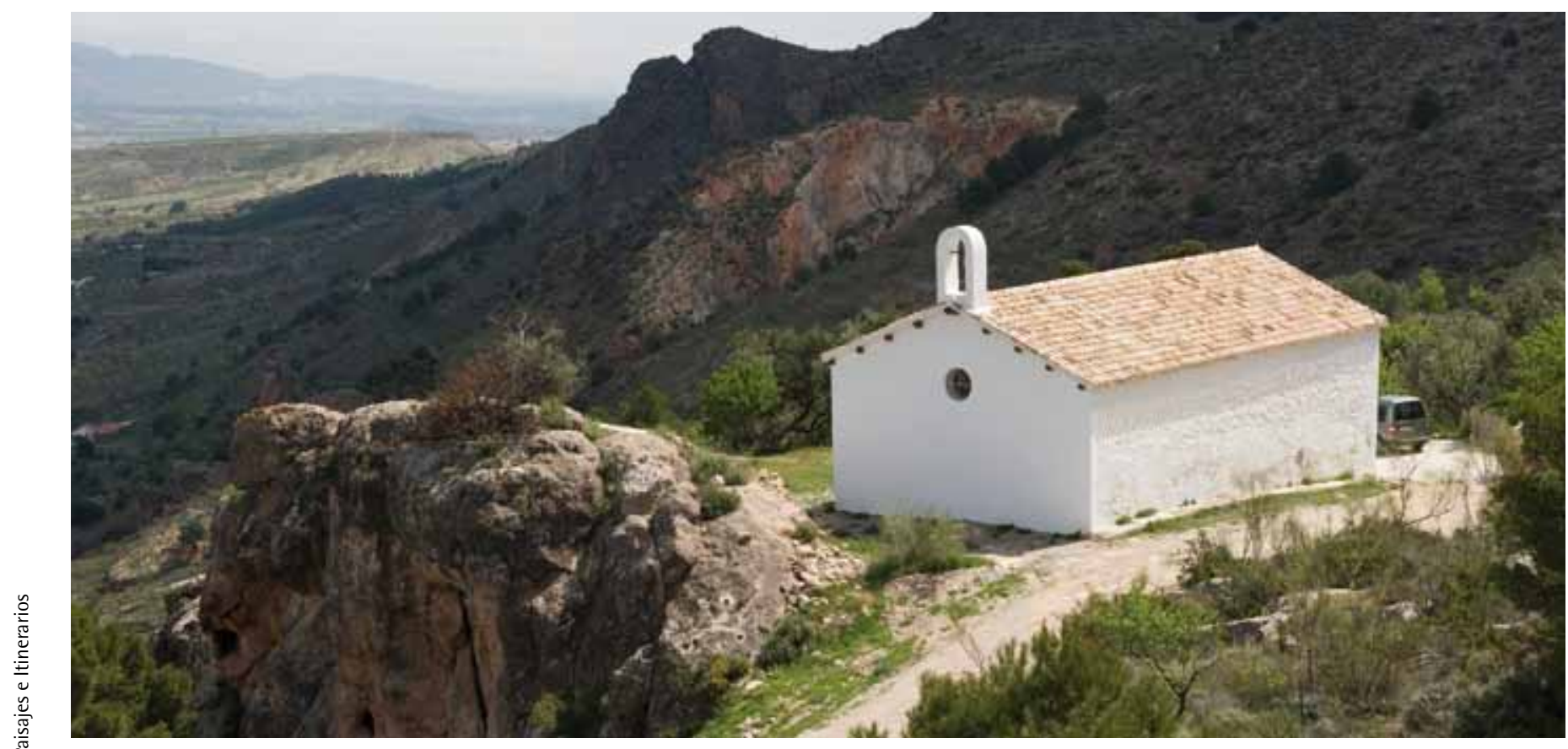

Ermita de la Virgen de la Cabeza (Serón). Foto: Fondo Gráfico IAPH Uuan Carlos Cazalla) 

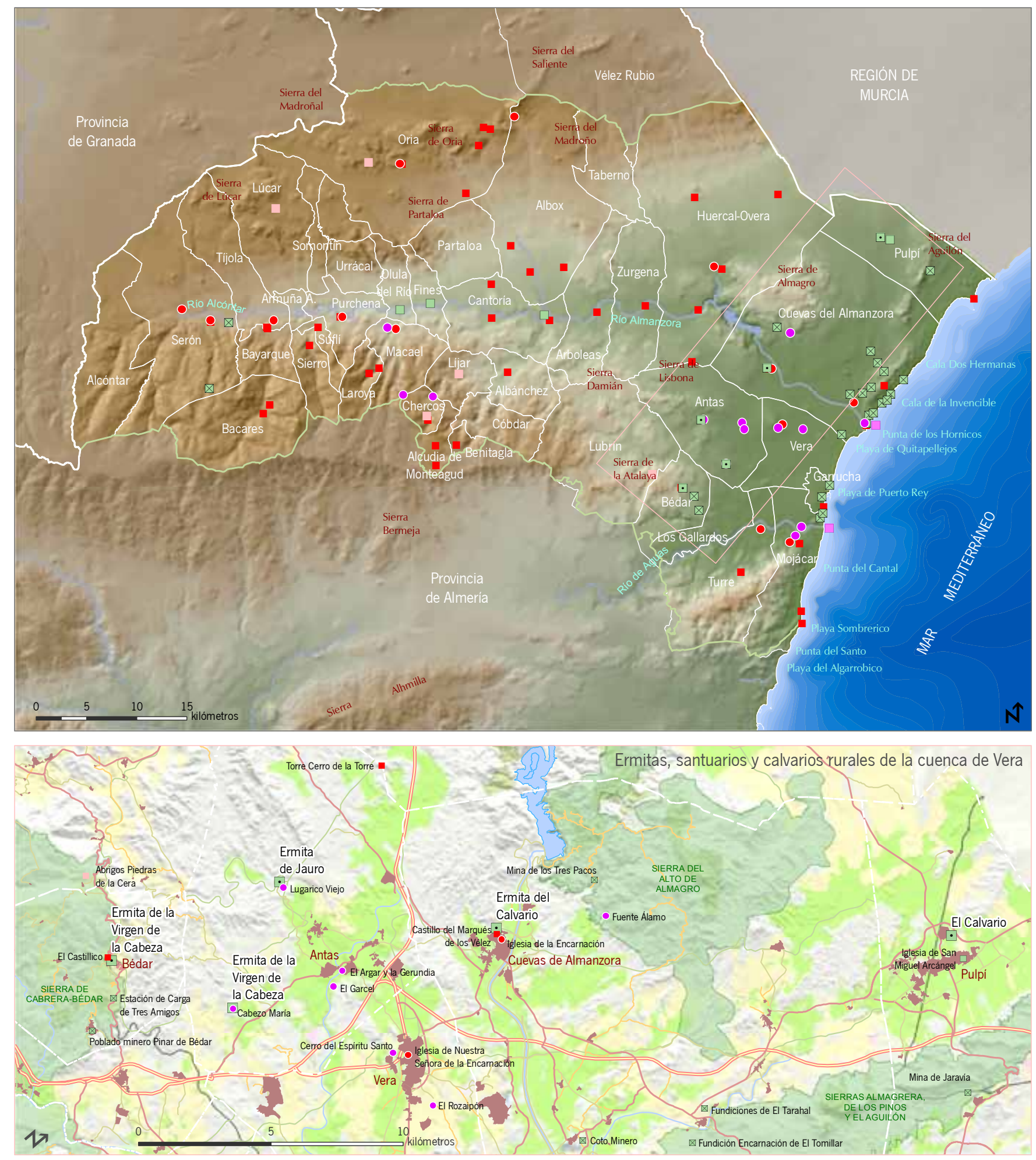

\section{Bien de Interés \\ Cultural \\ - Monumento \\ - Zona Arqueológica}

Bien de Catalogación General $\square$

44 Bienes Inmuebles del Patrimonio Minero Industrial $\quad \square$

D. A. $6^{a}$ (Ermitas, santuarios y calvarios cuenca de Vera) •

Zona de Servidumbre Arqueológica
El Catálogo General del Patrimonio Histórico Andaluz en el Valle del Almanzora 